\title{
SURGICAL ASPECT OF BLEPHAROSPASM TREATMENT: A CASE REPORT
}

\author{
Kristijan Dinjar ${ }^{1,2}$, Vedran Zubčić ${ }^{1,2}$, Andrijana Kopić, , $^{13}$, Vlatko Kopić1,2, \\ Bruno Popić ${ }^{1,2}$ and Dubravka Holik ${ }^{1}$
}

\begin{abstract}
${ }^{1}$ Faculty of Medicine in Osijek, Josip Juraj Strossmayer University of Osijek, Osijek, Croatia; ${ }^{2}$ Department of Maxillofacial and Oral Surgery, Osijek University Hospital Centre, Osijek, Croatia; ${ }^{3}$ Department of Ophthalmology, Osijek University Hospital Centre, Osijek, Croatia
\end{abstract}

\begin{abstract}
SUMMARY - Blepharospasm is an idiopathic condition characterized by involuntary eyelid closure mainly caused by bilateral tonic-clonic contractions of the orbicularis oculi muscle. It results in patient inability to open their eyes, thus significantly impairing their ability to perform activities of daily living. First-line treatment for blepharospasm are primarily botulinum toxin type A injections. However, surgical procedure as a treatment option can also be taken in consideration. In this overview, we present a case of a 75-year-old female patient who received surgical treatment as per Anderson's method after being treated with botulinum toxin type A for 3 years. This form of therapy proved to be an extremely successful permanent solution in the treatment of severe cases of refractory blepharospasm, without any long-term complications, especially ectropion and lagophthalmos.
\end{abstract}

Key words: Blepharospasm; Anderson's method; Botulinum toxin type A

\section{Introduction}

Blepharospasm is a type of focal dystonia characterized by involuntary tonic contractions of the orbicular muscle ${ }^{1}$. These contractions lead to uncontrollable closure of the eyelids, making it difficult for patients to open their eyes spontaneously. Patients with blepharospasm complain of grittiness in the eye, eye dryness or photophobia and it is often confused with dry eye syndrome $^{2}$. The spasm can last from a few seconds to a few minutes, with periods of relaxation in-between. The condition often progresses to longer contraction phases and shorter relaxation phases. It typically occurs in older adults, more often in women. It is mostly bilateral, with possible cases of unilateral presentation. In addition to firmly shut eyelids, the facial nerve innervating other muscles can lead to further muscle con-

Correspondence to: Dubravka Holik, $M D, P h D$, Faculty of Medicine in Osijek, Josip Juraj Strossmayer University of Osijek, Josipa Huttlera 4, HR-31000 Osijek, Croatia

E-mail:dholik@mefos.hr

Received July 23, 2019, accepted January 22, 2020 tractions. The condition gradually limits patients in their activities of daily living, such as reading, watching television, working and social interaction ${ }^{3,4}$.

Whereas the etiology of this condition remains unknown, the fact that blepharospasm accompanies many extrapyramidal disorders leads to a presumption that the cause could be traced back to basal ganglia dysfunction. Genetic and environmental factors are also believed to play a role in the development of blepharospasm ${ }^{3,4}$.

The treatment of blepharospasm remains controversial to this day. Injecting botulinum toxin type A into the muscles of the periocular region is one of the most frequently applied methods. It improves motor symptoms of blepharospasm by decreasing muscle contraction and involuntary dystonic movement and posturing ${ }^{5}$. It usually leads to temporary improvement ${ }^{6}$.

As for surgical methods, in the past, selective resection of facial nerve branches (Reynold's method) was the preferred method of treatment, often resulting in ectropion and lagophthalmos ${ }^{7}$. Current surgical ap- 

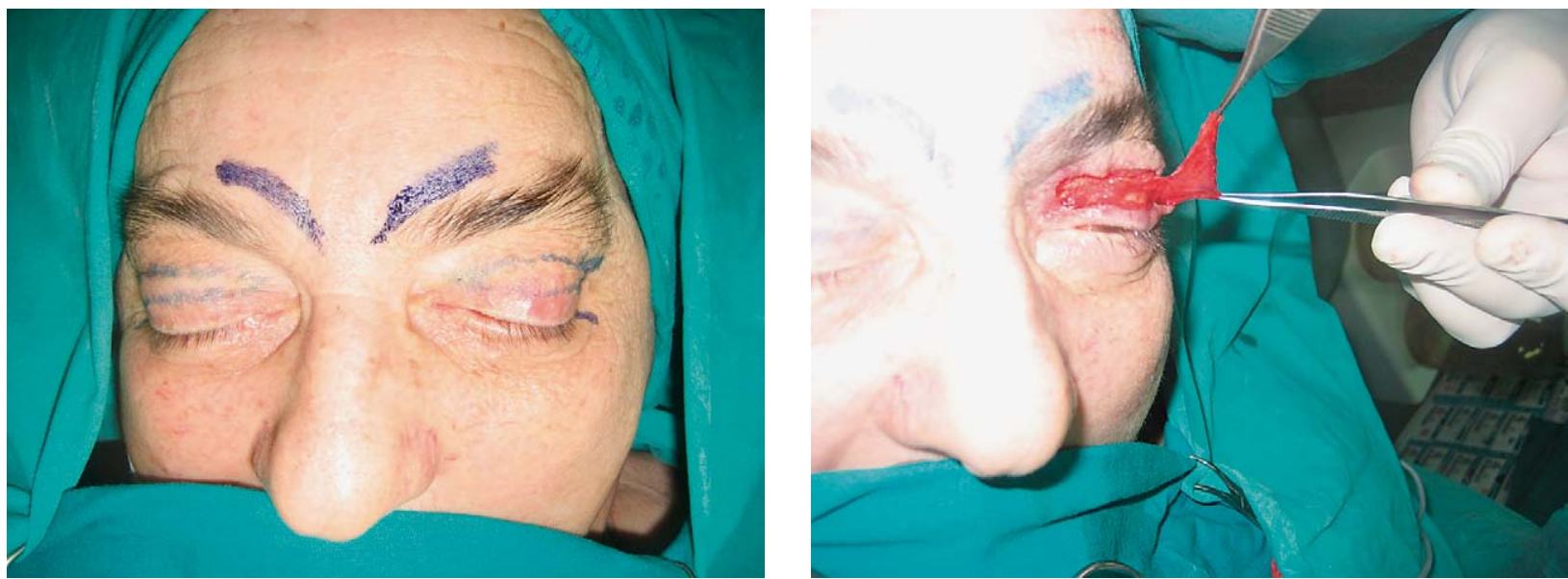

Fig. 1. Preoperative marking of forehead and upper eyelid incisions and resection of part of the orbicularis oculi muscle.
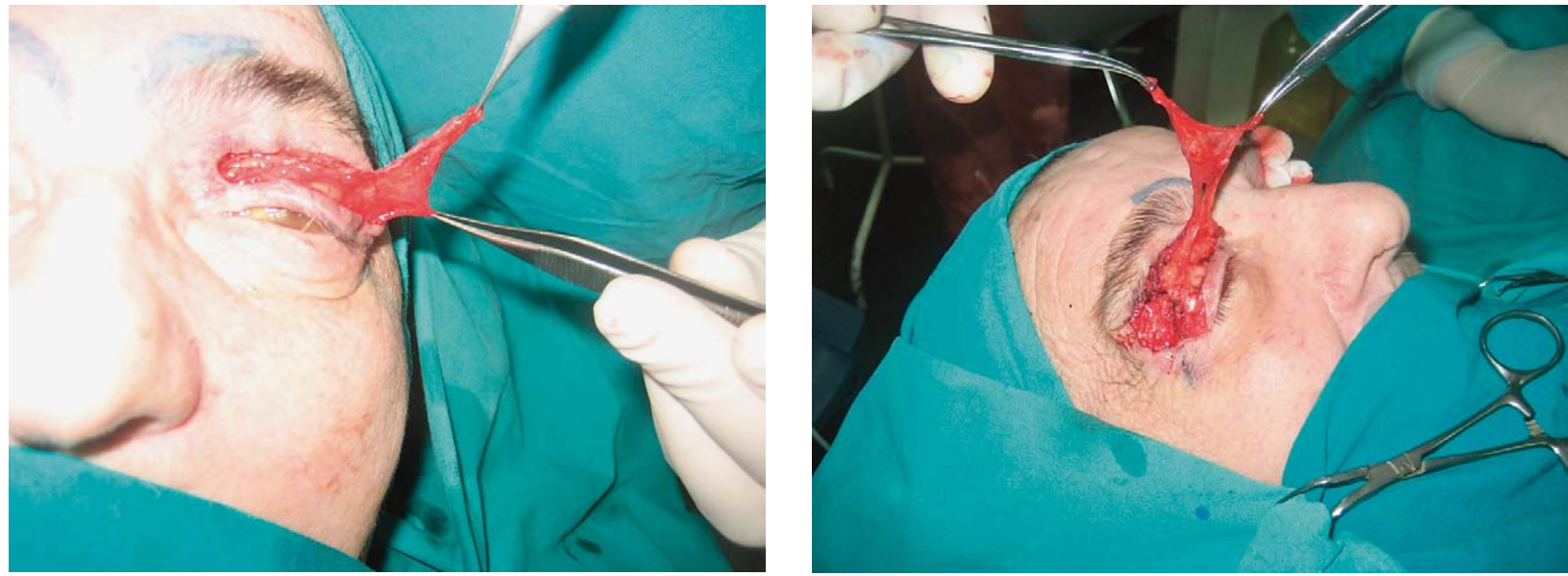

Fig. 2. Resecting two-thirds of the left and right orbicularis oculi muscle through the upper blepharoplasty incision whilst preserving its medial portion.

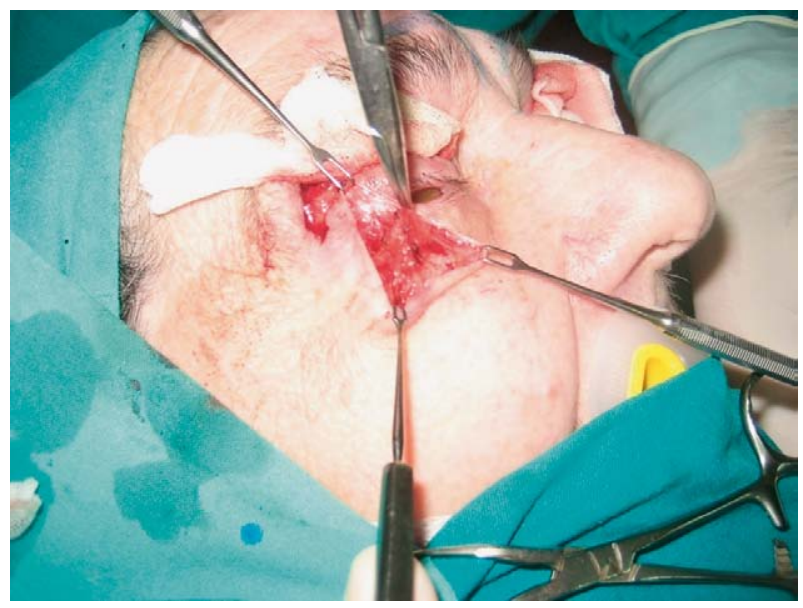

Fig. 3. Resecting the lateral half of the orbicularis oculi muscle through the lower blepharoplasty incision. proach rests upon applying anatomical knowledge related to peripheral branches of the facial nerve, as well as on understanding the functions of individual orbicularis oculi portions. Therefore, currently the most frequently used method is Anderson's method based on selective removal of the orbicularis oculi muscle, resulting in nearly complete resolution of symptoms with none of the above-mentioned complications ${ }^{8}$.

In this overview, we present a case of a 75 -year-old female patient previously unsuccessfully treated with botulinum toxin type A for three years. Subsequently, the patient underwent surgical treatment that led to complete resolution of the symptoms without any of the complications that accompany periocular surgery. 

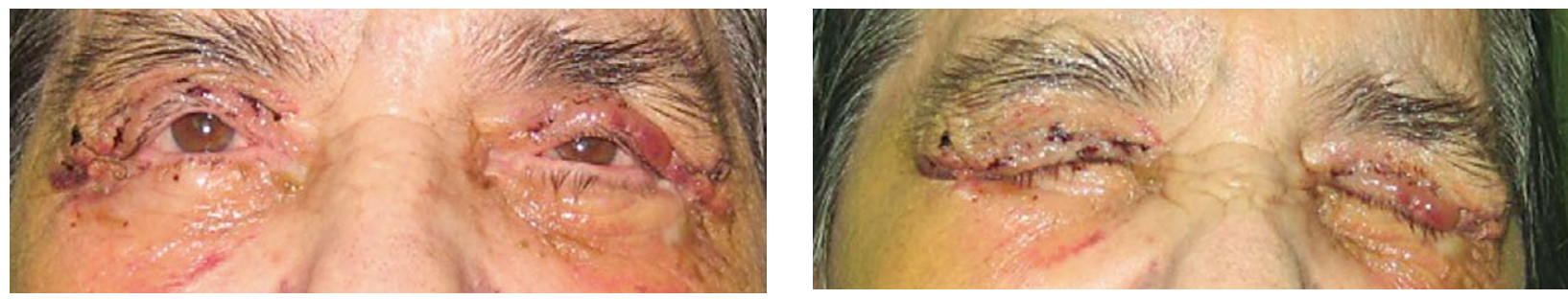

Fig. 4. Early postoperative result of surgical treatment of blepharospasm as per Anderson's method.
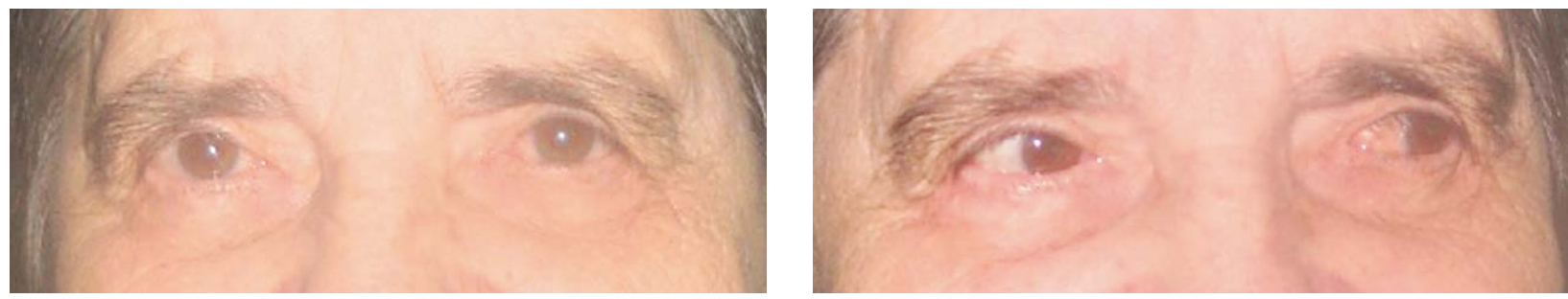

Fig. 5. Late postoperative result of surgical treatment of blepharospasm as per Anderson's method.

\section{Case Report}

In March 2012, an ophthalmologist referred the patient to the Department of Maxillofacial Surgery, Osijek University Hospital Centre, due to refractory essential blepharospasm previously unsuccessfully treated with botulinum toxin type A. The patient had diabetes and hypertension and was regularly taking oral antidiabetic and antihypertensive medications. She did not smoke or drink alcohol and had no known allergies to food or medications.

Clinical assessment showed bilateral upper eyelid blepharochalasis with signs of senile ptosis, as well as intense uncontrollable spasmodic closure of the eyelids. Interestingly, the patient had to hold her eyelids open with her hand in order to be able to see.

Upon hospitalization, the anesthesiologist postponed the operation three times due to refractory hypertension and poorly controlled diabetes. After adjustment of antihypertensive and antidiabetic therapy, an informed written consent for the surgery was obtained from the patient and she underwent surgery as per Anderson's method ${ }^{8}$.

\section{Surgical procedure}

An incision was made on both upper eyelids for upper blepharoplasty, followed by removal of twothirds of the orbicularis oculi muscle whilst preserving its medial portion. Next, the levator palpebral muscle tendon was shortened, followed by bilateral suspen- sion of the tarsal muscle. The forehead was approached under the remainder of the upper part of the orbicularis oculi muscle. The corrugator supercilii and procerus muscles were bilaterally exposed and transected. Layered closure was applied to upper eyelid wounds.

Bilateral incisions were made on lower eyelids for lower blepharoplasty. After exposing orbicularis oculi muscles, their lateral halves were bilaterally resected. Excess skin was removed and wounds were closed primarily by placing individual sutures (Figs. 1-3).

\section{Early postoperative period}

The patient was recovering well, wounds were healing with no signs of dehiscence or infection. The patient had bilateral periorbital hematoma with decreasing edema. She no longer suffered from blepharospasmic seizures or eyelid ptosis. Her state being improved, the patient was discharged home to self care and instructed to apply antibiotic ointments to her eyes twice a day. On the first postoperative visit, clinical findings were significantly improved, wounds were healing properly with bilaterally irritated conjunctiva. Consequently, the patient was referred to an ophthalmologist (Fig. 4).

\section{Late postoperative period}

The patient underwent regular follow-up examinations; clinical findings were completely normal, with no signs of infection, irritation of conjunctiva or new 
blepharospasmic seizures. At 21 months after the surgery, she was able to open her eyes without any problems, with no signs of lagophthalmos or other complications often related to surgical interventions in the periocular region (Fig. 5).

\section{Discussion}

To this day, there remain many issues regarding the treatment of blepharospasm. Different authors present different techniques and treatment options with various success rates and complications ${ }^{9-13}$. The most frequently used treatment option, believed by some authors to be the most effective one, is chemical treatment by means of injecting botulinum toxin type A, thus blocking nerve impulses 6 . Botulinum toxin type $A$ is injected into the muscles surrounding the eye to weaken them. It can be applied for several years, with at least 10-12 weeks between treatments so as to prevent resistance. The possible treatment complications include eyelid ptosis and blurred or doubled vision, which, however, disappear within 3 weeks, whereas the positive effects last for up to 4 months. Surgical treatment methods are primarily based on partial or complete myectomy. Complications include periorbital swelling, ectropion, corneal irritation and numbness or hypersensitivity in the region above the eye $\mathrm{e}^{6}$. Alternatively, selective resection of facial nerve branches ${ }^{14,15}$ can be performed, especially according to Reynold's method, previously considered the method of choice in surgical treatment ${ }^{7}$. According to some authors, as opposed to surgical myectomy, resection of facial nerve branches may be accompanied by a wider range of complications, especially ectropion and lagophthalmos $^{16}$. Moreover, long-term disorder recurrence goes up to $50 \%$ and many patients do not find the aesthetic result satisfying ${ }^{17}$. Another mentioned surgical option is frontal muscle suspension in patients with a special apractic type of blepharospasm ${ }^{18-20}$. This minimally invasive technique proved to be very effective, however, it requires continued therapy with botulinum toxin in order to balance the frontal muscle and orbicularis oculi muscle ${ }^{21}$. Nowadays, Anderson's method is considered to be one of the best surgical techniques in treating refractory blepharospasm ${ }^{8}$. As opposed to Reynold's method, this method facilitates correction of the existing anatomic defects resulting from longterm blepharospasm and thus guarantees a more fa- vorable aesthetic result. Therapy success rate ranges between $80 \%$ and $90 \%{ }^{22}$. Botulinum toxin can be considered as the first-line treatment for blepharospasm. Nevertheless, persistent cases call for a surgical approach $^{23}$. In our experience, Anderson's treatment method represents an excellent choice in treating such patients and provides permanent symptom relief with a negligible range of complications.

\section{Conlusion}

If left untreated, blepharospasm can become a serious burdensome condition. In mild cases, conservative treatment with botulinum toxin type A injections leads to satisfactory results. In more severe, refractory forms of blepharospasm, surgical therapy is the method of choice. Surgical treatment of blepharospasm should be based on applying anatomical knowledge related to peripheral branches of the facial nerve, as well as on understanding the functions of individual orbicularis oculi portions, with the aim of avoiding frequent complications arising from surgical interventions in the periocular region, such as lagophthalmos and ectropion. Making the right surgical choice leads to permanent favorable results in the treatment of blepharospasm.

\section{References}

1. Biuk D, Vinković M, Matić $S$, Bradvica M, Biuk E, Benašić T. Sensitivity of diagnostic tests for dry eye in patients with blepharospasm. Acta Clin Croat [Internet]. 2017;56(3): 375-81. [accessed:Jun 14,2019] doi: https://doi.org/10.20471/ acc.2017.56.03.03

2. Biuk D, Vinković M, Barać J, Biuk E, Zelić Z, Matić S. Protective effect of blepharospasm on the anterior segment of the eye. Acta Clin Croat [Internet]. 2018;57(1):130-3. [accessed: Jun 14, 2019] doi: https://doi.org/10.20471/acc.2018.57.01.16

3. Henderson JW. Essential blepharospasm. Trans Am Ophthalmol Soc. 1956;54:453-520.

4. Jankovic J. Clinical features, differential diagnosis and pathogenesis of blepharospasm and cranial-cervical dystonia. Adv Ophthalmol Plast Reconstr Surg. 1985;4:67-82.

5. Tang M, Li W, Ji F, Li X, Zhang Y, Liu P. Impact of botulinum toxin injections on quality of life and self-esteem in patients with blepharospasm. Psychol Health Med. 2019 Jun;24(5): 513-8. doi: 10.1080/13548506.2018.1549740.

6. Whitney CM. Benign essential blepharospasm. Neurologist. 2005 May;11(3):193-4. doi: 10.1097/01.nrl.0000161996. 06364.dc 
7. Reynolds DH, Smith JL, Walsh TJ. Differential section of the facial nerve for blepharospasm. Trans Am Acad Ophthalmol Otolaryngol. 1967;71:656-64.

8. Anderson RL, Patel BC, Holds JB, Jordan DR. Blepharospasm: past, present, and future. Ophthalmic Plast Reconstr Surg. 1998 Sep;14(5):305-17.

9. Dorzbach RK. Complications in surgery for blepharospasm. Am J Ophthalmol. 1973;75(1):142-7.

10. Batissa AF. Surgical therapy for blepharospasm. Adv Neurol. 1983;37:215-24.

11. Fox SA. Essential (idiopathic) blepharospasm. Arch Ophthalmol. 1966;76:318-21.

12. Patel BC. Surgical management of essential blepharospasm. Otolaryngol Clin North Am. 2005 Oct;38(5):1075-98. doi: 10.1016/j.otc.2005.03.016

13. Ben Simon GJ, McCann JD. Benign essential blepharospasm. Int Ophthalmol Clin. 2005;45(3):49-75.

14. Fante RG, Frueh BR. Differential section of the seventh nerve as a tertiary procedure for the treatment of benign essential blepharospasm. Ophthalmic Plast Reconstr Surg. 2001 Jul;17 (4):276-80.

15. Nemoto Y, Kaneko H, Serizawa R. Superselective neurectomy with periorbital primary reconstruction for blepharospasm. Case report. Scand J Plast Reconstr Surg Hand Surg. 2000 Sep;34(3):265-8.

16. Bates AK, Halliday BL, Bailey CS, Collin JR, Bird AC. Surgical management of essential blepharospasm. Br J Ophthalmol. 1991;75(8):487-90. doi: 10.1136/bjo.75.8.487
17. Frueh BR, Callahan A, Dortzbach RK, Wilkins RB, Beale HL, Reitman HS, Watson FR. The effects of differential section of the VII ${ }^{\text {th }}$ nerve on patients with intractable blepharospasm. Trans Am Acad Ophthalmol Otolaryngol. 1976;81: 595-602.

18. De Groot V, De Wilde F, Smet L, Tassignon MJ. Frontalis suspension combined with blepharoplasty as an effective treatment for blepharospasm associated with apraxia of eyelid opening. Ophthalmic Plast Reconstr Surg. 2000 Jan;16(1):34-8.

19. Roggenkämper $P$, Nüssgens $Z$. Frontalis suspension for essential blepharospasm unresponsive to botulinum toxin therapy. First results. Ger J Ophthalmol. 1993 Nov;2(6):426-8.

20. Smet H, De Wilde F, Tassignon MJ. Surgical technique for patients with the apractic type of essential blepharospasm: case report. Bull Soc Belge Ophthalmol. 1994;254:85-8.

21. Wabbels B, Roggenkämper P. Long-term follow-up of patients with frontalis sling operation in the treatment of essential blepharospasm unresponsive to botulinum toxin therapy. Graefes Arch Clin Exp Ophthalmol. 2007 Jan;245(1):45-50. doi: 10.1007/s00417-006-0392-5

22. McCord CD, Shore J, Putnam JR. Treatment of essential blepharospasm. II. A modification of exposure for the muscle stripping technique. Arch Ophtalmol. 1984;102(2):269-73.

23. Morrison DA, Mellington FB, Hamada S, Moore AT. Schwartz-Jampel syndrome: surgical management of the myotonia-induced blepharospasm and acquired ptosis after failure with botulinum toxin A injections. Ophthalmic Plast Reconstr Surg. 2006 Jan-Feb;22(1):57-9.

Sažetak

\title{
KIRURŠKI ASPEKTI LIJEČENJA BLEFAROSPAZMA: PRIKAZ SLUČAJA
}

\author{
K. Dinjar, V. Zubciic, A. Kopic, V. Kopic, B. Popici i D. Holik
}

Blefarospazam je idiopatska bolest kod koje dolazi do nekontroliranog stiskanja očnih vjeđa zbog najčešće obostranih toničko kloničkih kontrakcija kružnog očnog mišića. Takvo stanje kod bolesnika rezultira nemogućnošću otvaranja očiju i znatno ograničava obavljanje svakodnevnih aktivnosti. Terapija prvog izbora su injekcije botulinum toksina A, no u obzir dolazi i kirurško liječenje. Ovaj osvrt prikazuje slučaj bolesnice u dobi od 75 godina, kirurški liječene Andersonovom metodom nakon 3 godine liječenja botulinum toksinom A. Takav oblik terapije pokazao se veoma uspješnim trajnim rješenjem u liječenju težih slučajeva refraktornog blefarospazma uz izostanak dugoročnih komplikacija, osobito ektropiona i lagoftalmusa.

Ključne riječi: Blefarospazam; Andersonova metoda; Botulinum toksin tip $A$ 